\title{
Historia magister vitae
}

\section{Dra. Rosalba Fernández Contreras*}

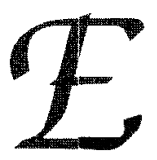

1 CEPE llega a sus ochenta años de vida... Estos aniversarios nos llevan inevitablemente al pasado, porque lo que es hoy el CEPE, es fruto de lo que fue en aquel ya lejano 1921 y de lo que ha sido en esa perseverante y rica senda que cubre ocho décadas.

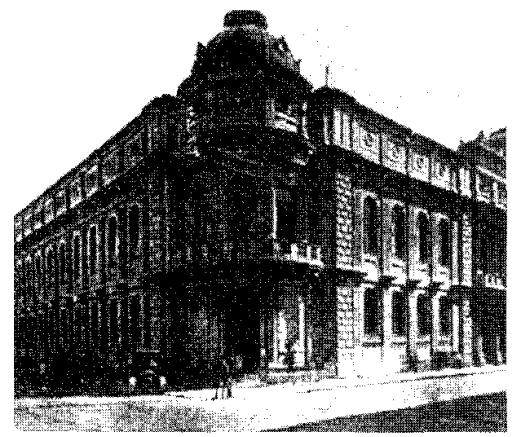

Edificio de Lic. Verdad, primera sede de la Escuela de Verano

Historia magíster vitae, el aforismo latino nos aconseja asomarnos a nuestra propia historia para aprender de los profesores que nos precedieron... Se han mencionado algunos nombres $y$ todos tenemos en la memoria varios más. Lo que todos ellos legaron a quienes hoy somos profesores en el CEPE (en los cinco CEPE) fueron caminos sabiamente trazados: una manera de acoger a los alumnos extranjeros, un sistema para elegir y organizar lo que hay que enseñarles, una didáctica para alcanzar nuestra meta de siempre, desde la Escuela de Verano hasta el CEPE: "Universalizar el conocimiento de la lengua española y de la cultura mexicana".

Desde su fundación, la Escuela de Verano enfrentó el reto de enseñar a extranjeros... Enseñar, transmitir conocimientos, es atra- yente, la meta final es el aprender del alumno: el estimulante binomio: enseñanza-aprendizaje.

Ahora bien, enseñar a extranjeros es, además de estimulante, todo un desafío a los conocimientos y formación del profesor, a su talento $y$ a su intuición didáctica. Porque al pararnos ante un grupo de unos 15 estudiantes, donde puede haber 15 diferentes nacionalidades y 15 lenguas distintas, el maestro del CEPE con una carrera terminada, estudios de una especialidad $y$ en muchos casos con posgrado, se pregunta:

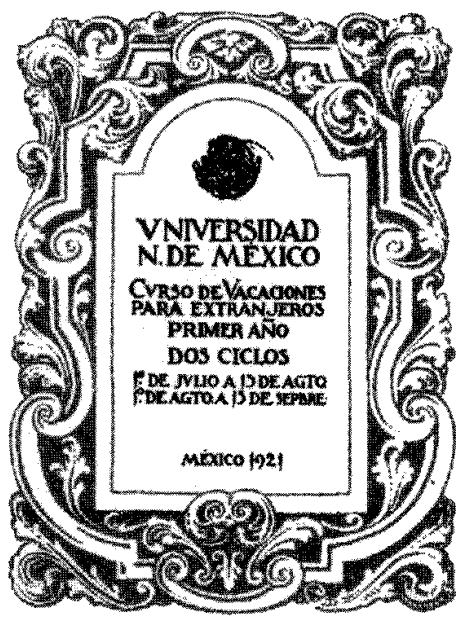

¿Cómo percibe cada uno de estos estudiantes no hispanohablantes, la expresión plástica del pueblo mexicano?

¿Cuáles fonemas del español "escuchan" sus oídos y cuáles son sólo ruidos para ellos?

¿Cómo entienden la realidad histórica de México a través de la cosmovisión personal y cultural que cada uno trae?

*Decana de los profesores del CEPE. 


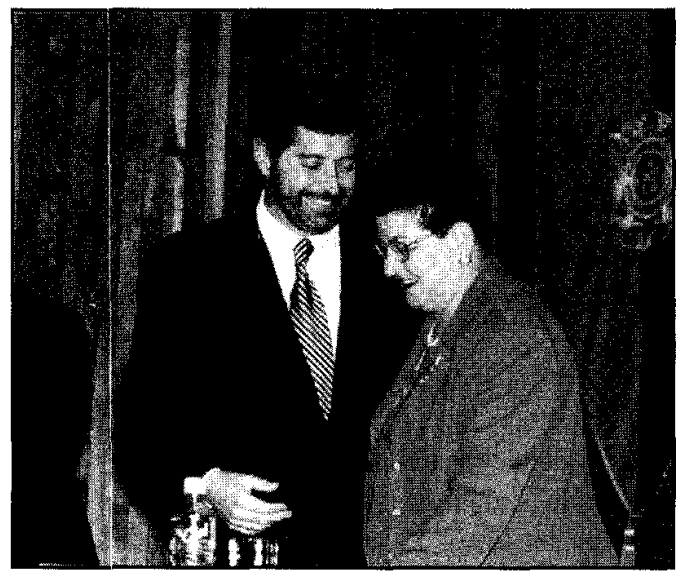

¿Cómo le explico la maleable y rica sintaxis del español a alguien que maneja una lengua monosilábica?

¿Qué hacer para que experimenten la musicalidad del texto poético, a la vez que penetran en el juego simbólicos de los contenidos?

Nada tan específico nos enseñó la carrera. Arite cada situación concreta hay que construir las respuestas a base de estudio y de vocación.

En el proceso enseñanza-aprendizaje es imprescindible el equilibrio entre lo dos elementos: sin alumno no hay maestro, sin docente difícilmente se da el aprendizaje.

Si en la UNAM el sector que menos tiempo permanece es el alumnado, en el CEPE es un elemento en extremo volátil: vienen por cursos de seis semanas o un semestre, tal vez cuatro cursos intensivos, es decir dos semestres... muy rara vez más tiempo.

Esta realidad y el trabajo docente que sinteticé líneas arriba, me permiten afirmar, sin falsa modestia y sin minimizar, ni mucho menos, el trabajo de cada una de las administraciones, que su profesorado es el elemento medular del CEPE. Es el baluarte que lo sostiene e impulsa desde 1921. Es este cuerpo docente, quien le da su peso académico, a fin de cuentas, su más valioso haber.

En la vida de los seres humanos a los 80 años se les llama vejez o, eufemísticamente, la tercera edad. Pero el CEPE para nada es "viejo", es una sólida institución siempre joven. Una vez más, gracias a sus maestros. Porque los maestros del CEPE no envejecemos: los individuos se transforman pero la esencia de ser maestro del CEPE no cambia

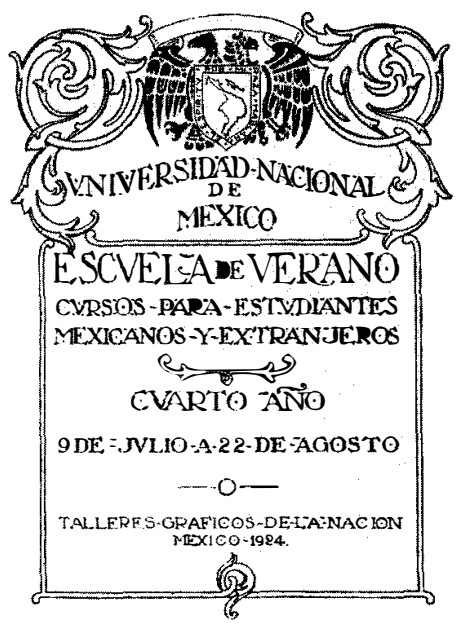

Afiches publicitarios de época

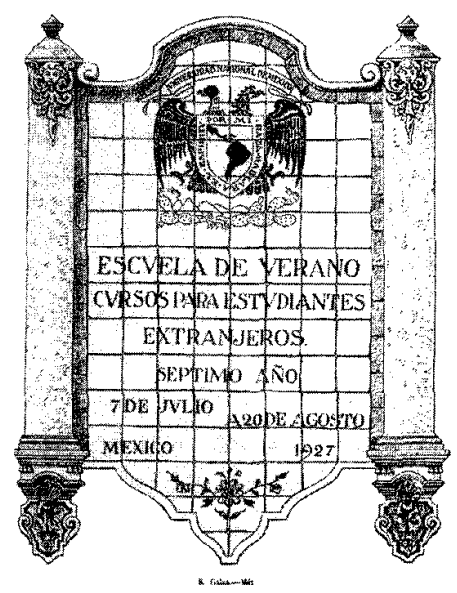

